\title{
UMA LIÇÃO PARA AS GERAÇÕES FUTURAS
}

\author{
Por Marcelo Pereira Binder \\ Professor da FGV-EAESP e da ESPM. \\ E-mail: mpb@fgvsp.br
}

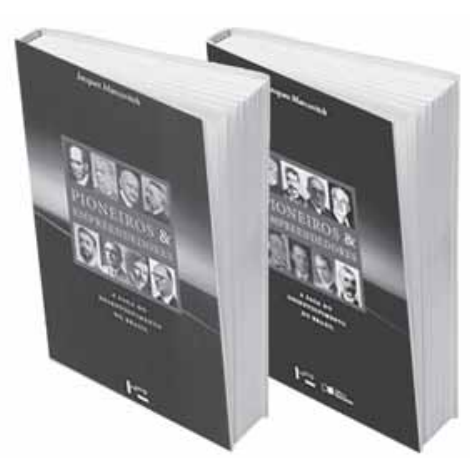

Composta por dois volumes, a mais recente obra do professor da FEAUSP Jacques $M$ arcovitch, Pioneiros \& empreendedores, resgata o passado empresarial brasileiro por meio da narrativa histórica, relatando 0 percurso de grandes empreendedores que transformaram nossa história econômica. 0 autor analisa a contribuição da obra de vida de 16 grandes empreendedores que, em sua época, influíram econômica, social e politicamente em nosso país. A obra, no entanto, vai muito além do resgate histórico: os dois volumes trazem importantes contribuições para a Administração atual, especialmente para o campo do empreendedorismo e para a gestão de empresas familiares.

O autor aponta, como público principal de seu livro, os estudan-

\section{PIONEIROS \& EMPREENDEDORES: A SAGA DO DESENVOLVIMENTO NO BRASIL}

De Jacques Marcovitch

São Paulo: Editora da Universidade de São Paulo, v. 1 (2003, 322 p.) e

v. $2(2005,328$ p.).

tes de Administração, que podem por meio de suas páginas aprender importantes lições para seu projeto de vida. Afinal, "empreender não consiste apenas em termos idéias próprias, mas em sabermos como os outros, antes de nós, conduziram à prática seus projetos de vida" (M arcovitch, 2005, p. 22).

A vida desses empreendedores pioneiros nos mostra que o grande empreendedor é aquele capaz de identificar e explorar novas oportunidades por meio da combinação de recursos existentes em novas formas para atender a novos mercados, seguindo o que Joseph Schumpeter denomina destrui ção criativa. Olhar esses homens como simples donos do capital seria um reducionismo, e pouco ou nada contribuiria à compreensão do desenvolvimento de nosso país. E mais: poderia fazer com que importantes lições de suas trajetórias passassem despercebidas.

O empreendedor é diferente da figura de um empresário capaz de extrair lucros em seus negócios, aproximando-se mais da figura de um agente de mudanças responsável por inovações que transformam a realidade. Os dois volumes, repletos de exemplos que ilustram essa afirmação, tornam a leitura bastante agradável e envolvem o leitor.

0 prazer da leitura do texto é fruto da escolha do autor de não se prender a normas acadêmicas tradicionais e rígidas. 0 autor adota a perspectiva da nova história para a elaboração dos perfis biográficos, que tem em Fernand Braudel um dos principais expoentes. Essa metodologia possibilita uma narrativa 
dinâmica, que mostra os personagens em seu contexto de atuação, a evolução dos seus negócios, estilos de gestão, os seus momentos duros e de decepção. 0 texto desperta no leitor a curiosidade sobre o passado da construção das nossas empresas e o estimula a buscar mais informações sobre os grandes empresários de nossa história. Isso porque, apesar da capacidade do autor de resumir com grande habilidade e sel etividade as informações sem prejudicar o entendimento, 0 espaço de 650 páginas é curto para a riqueza da história dos 16 grandes pioneiros abordados no livro.

Marcovitch selecionou os pioneiros não somente porque eles obtiveram sucesso financeiro, mas também por suas características marcantes, tipificando o homem de negócios, refletindo a estrutura econômica, as possibilidades e dificuldades de uma época. No primeiro volume encontramos os Prado, que representam a passagem de uma economia primária e exportadora para uma economia industrial e urbana; Nami Jafet, precursor da industria têxtil no país, que al terou as práticas comerciais do varejo; e Francisco Matarazzo, que personificou a imagem do industrial moderno da época e representou a formação da grande industria e do crescimento por meio da verticalização, quando a economia ainda era carente de infra-estrutura. 0 autor também escreve sobre 0 arquiteto Ramos de Azevedo - grande empresário da construção -, que, numa época em que os tijolos eram itens de importação, mudou a paisagem do estado, além de ter sido um dos fundadores e professor da Escola Politécnica; Jorge Street, um visionário do campo social, que trouxe como inovação a mudança nas rel ações da indústria com os trabalhadores;
Roberto Simonsen, um "intelectual de ação" que, além do sucesso como empresário, foi membro da Academia Brasileira de Letras; Júlio M esquita, fundador do jornal O Estado de S. Paulo, que influenciou a opinião pública e deu forte apoio à criação da Universidade de São Paulo; Leon F effer, que começou como comerciante de papel e, posteriormente, apostou na tecnologia para criar a atual Cia. Suzano de Papel e Celulose e, como líder comunitário, ajudou a criar o Hospital Albert Einstein.

No segundo volume encontramos o barão de Mauá - criador da primeira grande indústria nacional, do primeiro grande banco e da primeira estrada de ferro - , um homem que conheceu a falência e grandes sucessos, inclusive internacionalmente; Luiz de Queiroz, precursor do agronegócio no Brasil e fundador da Escola de Agronomia da USP, que leva o seu nome; Attilio Fontana, menino pobre, sem curso primário completo, que prosperou no comércio de suínos e fundou o frigorífico Sadia; Valentim dos Santos Diniz, fundador do Grupo Pão de Açúcar que, em sua época, alterou a operação do varejo brasileiro; Guilherme Guinle, grande incentivador da pesquisa, que ficou na história como o dono da Companhia Docas de Santos. E, ainda, os LaferKlabin, responsáveis pela primeira grande indústria de celulose brasileira; José Ermírio de Moraes, que se juntou ao sogro no desenvolvimento do Grupo Votorantim, presente em vários setores da economia; e os Gerdau-J ohannpeter, que, de uma fábrica de pregos, criaram um grupo brasileiro internacionalizado.

Fizeram parte do perfil desses homens as características próprias dos empreendedores: visão de futu- ro, sensibilidade estratégica, forte disposição para o trabalho, flexibilidade, capacidade de lidar com grandes incertezas e, sobretudo, capacidade de inovar. Foram personagens que desempenharam um papel ativo na vida nacional, de vidas significativas, cuja trajetória tem muito a ensinar às gerações atuais. Foram capazes de desenvolver recursos humanos para a gestão de suas empresas e mostraram que o conhecimento é tão importante quanto os recursos.

Dos empreendimentos abordados no primeiro volume, apenas a $\mathrm{Cia}$. Suzano de Papel e Celulose e a empresa $\mathrm{O}$ Estado de S. Paulo prosperaram até os dias atuais. As outras empresas não conseguiram se adaptar aos novos tempos e não tiveram nos sucessores os gestores capazes de dar continuidade à obra dos fundadores. No segundo volume, à exceção de Mauá, todas as empresas são hoje grandes grupos com forte presença na economia brasileira.

A obra também remete à discussão sobre gestão de empresas familiares, uma vez que no Brasil a família marcou a vida empresarial e, ainda atualmente, as maiores empresas são familiares. Assim, tratase de tema rel evante no país para o campo da Administração. Dar continuidade à empresa por meio de um sistema capaz de manter a boa gestão sem perder as forças que advêm da empresa familiar é um desafio para os gestores e um fenômeno a ser estudado pelos acadêmicos brasileiros.

O livro cumpre sua proposta de resgatar o passado para ajudar a formação dos gestores e empreendedores atuais e futuros. Adicionalmente, levanta questões para a reflexão e para o debate de temas contemporâneos e importantes para o nosso desenvolvimento. 